\title{
Narratives of success and narratives of failure: representations of the career of King Hugh of Italy (c.885-948)
}

Hugh of Arles, King of Italy between 926 and 947, has come to be regarded as one of the more successful kings of Italy in the tenth century. The evidence of his charters supports this conclusion, showing how effectively he managed to insert members of his own Provençal family into the existing political fabric of northern Italy. Contemporary narrative sources tell the same story but as one of failure. For Rather of Verona, Liutprand of Cremona and even Flodoard of Reims, Hugh and his family were suspect and their sexual mores questionable.

Their texts intervened in contemporary politics not simply as records of Hugh's inadequacies but as real political actors which helped to make that failure happen.

The career of Hugh of Arles as King of Italy between 926 and 947 is the focus of this article. ${ }^{1}$ He became king of Italy in the summer of 926 aged 40 and was already an experienced ruler in Provence, where he had acted as regent for his cousin Louis the Blind since $911 .^{2}$ His deep roots in the Provençal town of Vienne, ${ }^{3}$ and significant connections with Burgundy, ${ }^{4}$ persisted throughout his life. Nonetheless he is best known to historians as the Italian king. During his relatively long life he had three (possibly four) wives, ${ }^{5}$ at least five other established relationships with women (his 'concubines'), ${ }^{6}$ and nine known children, all but two born outside his official marriages. ${ }^{7}$ Lothar, his only legitimate son born to his second wife Alda, was made co-ruler in 931 at a very young age, ${ }^{8}$ when Hugh was over 50 . By the time he agreed to 'retire' to Provence under pressure from Berengar marquis of Ivrea, formerly his 'beloved retainer', dilectum fidelis, ${ }^{9}$ in the summer of $947,{ }^{10}$ he was over $60 . \mathrm{He}$ stepped aside on the understanding that Lothar, who had come of age not long before, would take his place as king: but this was only in name as Berengar was in charge and the arrangement ended in 950 when Lothar died, either of disease or poisoning engineered by Berengar (the sources do not agree). ${ }^{11}$ That death effectively marked the end of Hugh's 
influence in Italy. His dynastic plan had failed. Control of the kingdom was contested throughout the 950s between Berengar II (who died in 966) and the upstart Otto of Saxony (who conclusively established himself in 962 when he was crowned emperor). ${ }^{12}$ Although some of Hugh's remaining children may have lived through some of those events none of them challenged for the kingship, not even Hugh's powerful illegitimate son Hubert. ${ }^{13}$

Hugh's reign is relatively well-documented for the period, and recently historians have tended to view it more favourably than in the past voicing the opinion that Hugh was a successful, even creative, king. ${ }^{14}$ Patrick Geary has described Hugh as 'vigorous, capable and innovative'. ${ }^{15}$ Chris Wickham has characterised him as effective and energetic. ${ }^{16}$ Giuseppe Sergi has suggested that his methods of rule were 'radical' especially his deliberate creation of a new political elite to replace the old. ${ }^{17}$ Reappraisal of the substantial corpus of Hugh's surviving charters (83 in total) has driven this tendency to see Hugh as more a success than a failure, particularly in his careful and effective management of an extended network of relatives and friends. ${ }^{18}$ Issued between 7 August 926 just after he had become king of Italy, ${ }^{19}$ and his own death in 948 (10 April),${ }^{20}$ there survive roughly four for each year. ${ }^{21}$ Hugh's friends and associates, both men and women, clearly benefitted from his largesse, often repeatedly. ${ }^{22}$ There are 35 different petitioners reported, some of whom petitioned on several occasions including Bishop Sigifred of Parma (eight times), ${ }^{23}$ Queen Alda and Marquis Berengar of Ivrea (five times each), ${ }^{24}$ and Countess Ermengard and Bishop Ambrose of Lodi (four times each). ${ }^{25}$ Alda was Hugh's second wife and designated consors regni. Ermengard was his half-sister, the daughter of his mother Bertha and her final husband Adalbert of Tuscany. They were clearly with Hugh early in his reign, helping him to consolidate the power of the family in this region. Neither woman figured as a petitioner after 932 (once Lothar had joined his father as co-king) or as a beneficiary. However, both acted in favour of the church in Parma, where Sigifred was bishop and he clearly benefitted quickly from the 
arrival of Hugh and his family. Churches in Parma benefitted on ten separate occasions between 926 and $944 .{ }^{26}$ By contrast, Bishop Ambrose's church of Lodi was never a beneficiary during Hugh's reign. The numbers of petitioners who appeared on three occasions was greater at seven individuals. The majority were magnates: Count Giselbert (his brother-in-law) in 926; ${ }^{27}$ Count Samson (929, 930 and 932); ${ }^{28}$ Marquis Boso (931, 932 and 933) $;^{29}$ Count Hilderic $(941,943) ;{ }^{30}$ Count Elisardo $(943,945) .{ }^{31}$ Two were bishops: Guy of Piacenza (931, 936 and 948) and Atto of Vercelli (948 and 950, i.e. after Lothar had taken over as sole ruler). ${ }^{32}$ Both of their churches were beneficiaries in Hugh's charters, Piacenza on nine occasions and Vercelli twice. The remaining petitioners appeared either once or twice, but among their number were significant people documented in other sources notably successive archbishops of Milan (926, 936, 947 twice and 950) and Hugh's illegitimate son Count Hubert $(942,943) .{ }^{33}$ Hugh's charters must, like other royal diplomas, therefore be read above all as political narratives, both written and oral. ${ }^{34}$

Surveying these charters at a macro level certainly confirms that Hugh relied upon his family connections to enable his rule. Their political language, which deserves much more specialist study than space will allow, occasionally reveals the warlike nature of his kingship. In the words of a grant issued in November 928 from Vienne by his chancellor Gerlan, Abbot of Bobbio to the monastery of Saint Oyen-de-Joux, he was 'the most invincible king' (rex invictissimus). ${ }^{35}$ By then, he had indeed subdued the Italian kingdom by force and thereafter all his and his son's charters were issued from within the kingdom whereas before some were issued from Vienne. ${ }^{36}$ But, although some charters repeat the convention that Hugh was a 'most pious king' (rex piissimus), in fact there is very little obviously religious language in the charters issued in his own name between 926 and 931. Few particularly pious sentiments are evidenced and no Biblical quotations. They are instead straightforward, rather plain, practical documents which appear to have little to say about the sacrality of Hugh's kingship. 
Judgments of the king are of course nothing new for exact and near contemporaries handed down their verdicts on Hugh and these, in marked contrast to those of modern historians, tended more toward failure than success. In the rest of this article I reassess these contemporary judgments by paying closer attention than is normal to the literary aspects of the surviving narratives in which Hugh was a protagonist. While reading these it is useful to bear in mind that 'concrete historical individuals perform rather complex operations with the language/s available to them, while at the same time their thinking is limited by the dominant metaphors and vocabularies'. ${ }^{37}$ Silvana Patriarca's linkage of performance, metaphor and vocabulary in an elaborate melange while voiced in a study of nineteenth-century discourses of the Italian Risorgimento is certainly a helpful formulation through which to read what are complex tenth-century political narratives.

The main evidence addressed here is a well-known series of highly politicised works written by an 'Ottonian' group of ecclesiastics including Rather of Verona (d.974), Liutprand of Cremona (d. c. 972) and Hrotswitha of Gandersheim (d. c. 1002), above all the salacious stories of the polemical 'Book of Revenge' (Antapodosis) which Liutprand wrote while a deacon at the end of the 950s as part of his campaign to become a bishop, which succeeded when Otto had him consecrated as bishop of Cremona in November or December $961 .^{38}$ Rather and Liutprand strongly condemned Hugh and other members of his extended family for 'immorality', especially sexual immorality, ${ }^{39}$ hardly surprising given the power of contemporary clerical discourse about the necessity of legitimate marriage overseen by the church. ${ }^{40}$ But these clerical writings were much more than that: they were self-consciously 'political' texts which, to appropriate the language used by Jason Glenn in the case of Richer of Reims, were written for a community of readers (or listeners) who had 'a stake in the events described'. In doing so the works themselves 'entered the political arena' ${ }^{41}$ These works can be termed 'contemporary history' deliberately intended to shape contemporary 
politics even though a variety of different genres with their own rules was employed in which to deliver the message. ${ }^{42}$ Genre and the specific conventions of a particular form are certainly important considerations but the compulsion to narrate and especially to narrate 'the' version of a story could always break its bounds. ${ }^{43}$ The collective picture of Hugh and his family in these narratives ('collective narratives' perhaps?) was firmly negative and it is often suggested that such hostility was consciously adopted for careerist reasons, ${ }^{44}$ especially a need to get on the right side of Otto the Great and to stay there if they were to stand any chance of weathering the political crisis that engulfed the Italian kingdom in the 950s. Rather desperately wanted to remain bishop of Verona and Liutprand to become bishop of Cremona. Although this motive is understandable they did not always know the outcome of the events they wrote about or indeed wrote to bring about. We do. Nor were they as well informed as we are about political events while they were writing. Therefore we must be careful not to read their works in a teleological way and, although such career-oriented explanations have some merit, it will be argued here that there are other ways of looking at these famous works.

One reason for challenging a careerist perspective is the simple fact that once work produced outside the charmed Ottonian circle is taken into consideration 'career' no longer works as an explanation. For example, the representation of Hugh as Italian king by Flodoard of Reims (d. 966), largely ignored within existing assessments of his reign, was also negative even though he was writing in Reims and seems to have had little to gain in career terms from criticising Hugh in order to gain favour with Otto. Added to this is the fact that other contemporaries thought that Hugh was a success rather than a failure, so pedalling a negative view of the king might not actually be successful as a career move. The anonymous 'Miracles of Saint Columbanus' (MSC) probably authored between 950 and $963 / 7$ by a monk of the famous monastery of Bobbio shows that it was at that date possible for a monk to approve of Hugh's political actions during an early stage in his Italian adventures when he was untried as 
Italian king. ${ }^{45}$ The text narrates the journey of the body of Columbanus from Bobbio to Pavia, significantly the capital of the kingdom, to help persuade Hugh to quash attempts by local bishops to appropriate monastic property. The miracles which resulted had the desired effect and that is why the text was written; yet the same narrative clearly demonstrated God's approval of Hugh as much as of Columbanus and Bobbio. Although obviously in a different genre from any of those employed by Rather, Liutprand or Hrotswitha, it is nevertheless significant that such a 'narrative of success' was possible after Hugh had died, and indeed it is possible to see it, like other later narratives, as an active participant in events which it helped to bring about as well as to document. ${ }^{46}$

Reconsideration of these narratives inevitably touches upon other themes which have concerned historians of the tenth century, especially the value or otherwise of biography, ${ }^{47}$ the supposed significance of descent from the Carolingians in this period, ${ }^{48}$ and the performative nature of charters as an essential part of political culture. ${ }^{49}$ For us biography is a common if contentious form of historical writing but whether tenth-century writers thought that 'biography' was such a category remains uncertain especially in light of debates about the 'discovery of the individual' in the twelfth century. ${ }^{50}$ There can be no doubt though that both Rather and Liutprand were self-reflexive writers, Liutprand musing on his 'inner self' at the outset of Antapodosis Book Six and Rather referring almost constantly to his feelings. They thought autobiographically and that surely informed their writing about contemporary politics including the activities of Hugh. If Hugh and his relatives are far too poorlydocumented to make anything approaching true psychological biography possible for them something closer is possible for Rather and Liutprand who seemed to foreground both autobiographical and biographical life-stories in their narratives. ${ }^{51}$ Chastity was a crucial part of these narratives. Unmarried ecclesiastics took chastity seriously unlike many of their contemporaries including kings like Hugh. Crucially, it prevented them from engaging with 
and benefitting from 'family politics' of the sort practiced by Hugh based as it was upon the fruits of his apparently numerous sexual encounters. But their narrative interventions circumvented that handicap by destroying Hugh's reputation for justice, causing him to lose the support of the 'Italian' aristocracy by portraying him as a 'Provençal', highlighting the illegitimacy of most of his children, and ruining his posthumous reputation into the bargain as eleventh-century memories of Hugh show. ${ }^{52}$ Their collective narrative power as authors, which in this respect went beyond the 'self-justificatory' nature of history-writing as a genre, ${ }^{53}$ more than matched the more formal, ritual narratives of royal charters and it was they, not Hugh's chancellors, who immortalised Hugh as a 'bad king'. Once written and sent out into the world works such as the 'Prefaces' and 'Book of Revenge', very much like Hugh's biological children, went their own ways actively participating in politics as well as commenting upon the political as is the more conventional way of reading them. ${ }^{54}$

Rather, Flodoard and Liutprand were hardly alone in having clear ideas about the qualities that a good king needed to possess. ${ }^{55}$ But because some of them had lived more closely in contact with the violent events through which Otto had ended Bosonid power in Italy it is on the surface unsurprising that they would blacken Hugh's reputation when they looked back retrospectively on his history. ${ }^{56}$ While most of these authors wrote at some point to obtain Otto's patronage that had not always been so: in particular Rather wrote before as well as after Otto was on the scene and Flodoard wrote with other audiences in mind. 'History' could be both contemporary comment and written memory. ${ }^{57}$

Rather devoted Books 3 and 4 of his extended 'Prefaces' (Praeloquia) to the subject of kingship. ${ }^{58}$ Four virtues were essential to a worthy king: justice (iustitia), wisdom (prudentia), temperance (sobrietas) and fortitude (virtus). ${ }^{59}$ This work was aimed at Hugh because he had removed Rather for 'treason' from the see of Verona (to which he had 
appointed him in 931) and imprisoned him in Pavia and Como between 935 and 937. Rather did not pull his punches when he suggested that 'your majesty not...distain to receive what must now be said in such a way that points which have perhaps long been unknown or overlooked may be made clear and corrected'. Born in the late 880 s he held to the established Carolingian view of the necessity of correctio (and admonitio) for all in society including the king. Indeed some Carolingian rulers, notably Charlemagne and Louis the Pious, were at the forefront of developing these ideas, and each had been corrected by contemporary clerics in respect of errant sexual behaviour. ${ }^{60}$ Rather went on to advise Hugh to fear God and to 'govern - or rather nourish - the people committed to you, respect the pious, honour bishops ${ }^{61}$ He was adamant that bishops ranked more highly than kings in the eyes of God but, unsurprisingly given his circumstances, he was sometimes cautious in attacking Hugh directly: for example he referred to the fact of his punishment 'by a certain person' (namely Hugh) as general knowledge without actually directly naming the king. ${ }^{62}$ But he did not pull back from accusing Hugh of abusing his position by his cavalier treatment of the priesthood, which he regarded as a far superior state to that of a king. ${ }^{63}$

These remarks (and many others like them) seemingly about kingship in general but actually about a specific king in particular (Hugh) were written during his confinement ordered by that king. They are hardly likely to reveal much of the 'real' Hugh but they do, like all of Rather's writing, reveal much of his personality. ${ }^{64}$ Later as a free man, although without a position and itinerant, he pondered his loss of Verona in a letter to Pope Agapetus II in the autumn of $951 .{ }^{65}$ By this time both Hugh and Lothar were deceased, succeeded by Berengar II but with the looming presence of Otto of Saxony on the horizon. ${ }^{66}$ This was obviously a crucial moment in the transfer of power from Hugh's family to Otto's and Rather, now in his seventies, took the chance to claim justice for himself by writing to the pope who was certainly in this situation a potential powerbroker. Rather gave a very clear 
summary of his case which included a dissection of his own relationship with Hugh. When Hugh had made his cousin Hilduin bishop of Verona (in 928), the king was 'at that time, as was believed, very fond of me'. ${ }^{67}$ Rather was encouraged to think that he would succeed Hilduin when the latter moved to higher things but when this came to pass in June 931 with Hilduin's promotion to the archbishopric of Milan

...the king decided far otherwise than he had promised (such is often the instability and fickleness of the world), desiring instead, as the story has it (ut fama erat), one of three: either one Aquitanus or one Garafridus or Manasses, archbishop of Arles, against the canons though it would be. ${ }^{68}$

Rather claimed that he had had a letter from Pope John XI supporting his candidacy which, supported in turn by Hilduin, ensured that he did indeed become bishop of Verona. 'This was very displeasing to the king, who was working towards something quite different...' he commented. ${ }^{69}$ Hugh agreed, having been persuaded that Rather was near death. He lived, was ordained and a furious Hugh (iratissimus) ${ }^{70}$ vowed that he would not enjoy his time as bishop (although Rather probably didn't have enjoyment in mind anyway). Hugh then found a pretext to expel Rather who, although he admitted some responsibility, stated that Hugh had acted 'against the law and without giving me a hearing' ${ }^{71}$ Rather, somewhat predictably, expressed his grief at the memory of Hugh having wished him 'the felicity of the emperor Theodosius', who famously had to do penance having been excommunicated by Ambrose of Milan in response to a massacre at Thessalonica and was thus an example of a ruler literally floored by a bishop. Rather had earlier held up the example of Theodosius as a merciful ruler to Hugh himself in the Praeloquia. ${ }^{72}$

The saga continued. Rather was released and Hugh 'by God's justice had been stripped of the honour of ruling' (by Berengar in 945). Rather had the idea of a rapprochement with Hugh who according to rumour was regretful of his treatment of Rather. Perhaps Hugh was merciful like Theodosius after all? But this scheme failed and Rather was arrested by Berengar instead, at the suggestion of Manasses, Hugh's nephew and by now 
Archbishop of Milan ('a most holy archbishop' as Rather put it with heavy irony) ${ }^{73}$ Count Milo, who 'so the story goes' (ut fertur) had 'greatly damaged Hugh', also turned against him. ${ }^{74}$ Rather was eventually restored to Verona, whereupon King Lothar threatened him with violence unless he gave up the see in favour of an appointee of Manasses. He then turned to the pope and to Otto who

...wanted the kingdom of Italy for no other pressing purpose than by imperial power to force the kingdom that had been wracked by many instances of wrongdoing of this kind and other injustices (inrectitudinum) into the justice (rectitudinum) of Christian law. ${ }^{75}$

He eventually regained Verona in 961.

Throughout this account Rather implies that word of mouth was a vital transmitter of political knowledge. Historians agree that fama ('reputation') was indeed a profound part of early medieval literary culture, as essential to that form of expression as to oral discourse ('gossip'). ${ }^{76}$ It was as vital in political action. Politicised narratives were written mostly by clerics who were trying both to record the events of their own times (in the sense of reporting factual happenings) but equally to shape the memory of those events for all time, and to reveal in that process how the hand of God operated upon all aspects of human existence. ${ }^{77}$ It is essential that the language these men (and the occasional woman) used is decoded, their vocabulary interrogated, their stock phraseology identified, the topoi they reiterated revealed and much else besides. ${ }^{78}$ Close textual reading demonstrates that clerical authors were nothing if not perennial gossips, and shows that they often helpfully, transparently and deliberately signalled that to readers in the simple but telling phrase 'it is said'. ${ }^{79}$ Rather did exactly this when narrating the shared history he had with King Hugh with the result that Hugh's point of view is (deliberately) lost.

Rather, of course, although complex linguistically was very transparent in his intentions. Other, more apparently sober and sensible authors who employed more direct language are more difficult to read (in both senses) and historians have to keep careful 
lookout for linguistic signs in such apparently 'simple' writers. One such was Flodoard of Reims (894-966), one of the best historians of the period. ${ }^{80}$ His views on Hugh and his family are valuable precisely because he was an outsider to the political world which Hugh had constructed in Italy, and indeed to the one he left behind in Provence. ${ }^{81} \mathrm{He}$ was also a close contemporary of the king's, roughly ten years younger than Hugh. He dealt with Hugh in his 'Annals' whose antics he recorded in a reasonable number of entries. ${ }^{82}$ These laconic records help to plot the king's contemporary reputation outside of Italy but at the time they also constructed that reputation, at least among Flodoard's readers and, in this world of talk, perhaps beyond. Given Flodoard's geographical focus upon north-east France, Hugh was inevitably a distant figure in his narrative, even though his information about the king seems to have come from knowledgeable sources including Rather and possibly also pilgrims from Reims returning from trips to Italy. ${ }^{83}$ Most of his entries on Hugh set the king's contemporary reputation in a context rather different from the more obviously partisan agendas of Italian authors, or those largely based in or writing about Italy. Flodoard's terse report of how Hugh became king of Italy in the summer of 926 - his first reference to him - is striking:

In Rome Hugh, son of Bertha, was constituted king over Italy after King Rudolf of Cisalpine Gaul had been expelled. Hugh travelled to that kingdom and married a woman even though his wife was still alive. ${ }^{84}$ This was after Burchard, the princeps of the Alamanni and father-in-law of this Rudolf, was killed by Bertha's sons. Burchard had crossed the Alps with Rudolf in order to regain the kingdom for his son-in-law. ${ }^{85}$

Flodoard was wrong on the location of Hugh's coronation, which took place at Pavia rather than Rome, on 9 July 926, but the rest is accurate except for the comment that Hugh was a bigamist. This statement was hardly necessary to telling the accession story and suggests that, like his Italian contemporary Liutprand, he intended his readers to understand that Hugh's questionable marital status was an essential part of his political persona, even the essential part of it. Quite who this 'woman' was is uncertain as Flodoard does not name her but he may have intended Marozia. The woman left behind was either his first wife Willa or Alda his 
second. The named woman is not a wife but Hugh's mother Bertha a reference which signalled Hugh's Carolingian lineage rather than his father's unmentioned ancestry. Perhaps her textual presence suggested to readers with some subtlety that Hugh was dominated by his mother calling into question the king's independence, his masculinity and the very fact of his kingship at what was a (perhaps the) crucial moment in his life. ${ }^{86}$ By this time Hugh's father Count Theobald of Arles was dead and Bertha had married again, to Adalbert II of Tuscany, a powerful local magnate who had the potential to become king of Italy himself. Their son Guy was thus Hugh's half-brother. Flodoard noted this latter relationship later under the year 928 but in this earlier entry chose for some reason not to name Guy. ${ }^{87}$ Flodoard dealt briefly with Hugh on four other occasions in his narrative. ${ }^{88}$ The king's death was not noted, a sure sign that Hugh's memory was not so important to Flodoard, ${ }^{89}$ particularly because he did record that Berengar was made king of Italy in 950 'when, as they say, King Lothar died of poisoning' ${ }^{90}$ A scandalous royal death was perhaps too good to pass over.

Flodoard, writing in Reims, maintained both physical and narrative distance from Hugh. He knew something about the king but not much and most of his entries were quite anodyne, apart from that initial charge of bigamy. The latter is however crucial evidence because so incidental and matter-of-fact that Hugh's image (his fama) was tainted for some contemporaries with marital and sexual irregularity. Such accusations were by the time Flodoard was writing part of the stock in trade of clerical historians, as Stuart Airlie, ${ }^{91}$ Mayke de Jong, ${ }^{92}$ Rachel Stone, ${ }^{93}$ Simon MacLean, ${ }^{94}$ Tim Reuter, ${ }^{95}$ and others have demonstrated. ${ }^{96}$ In Hugh's case bigamy was perhaps not simply a narrative topos casually employed but also a carefully chosen accusation, selected perhaps even unconsciously because it confirmed what Flodoard knew of Hugh's ancestry. As has been shown, he definitely knew that Bertha was Hugh's mother, and therefore he is likely to have known that her mother was Waldrada, that infamous 'seducer' of Lothar II, Carolingian ruler of Lotharingia, given the extent of the 
gossip circulating around that case in the latter decades of the ninth century at Reims itself. ${ }^{97}$ This single reference in Flodoard therefore raises the possibility that Hugh's ancestry may well have been the fundamental ground upon which his contemporary reputation was built (by Rather, Flodoard, Liutprand and others) because both sides of his family were in the eyes of Carolingian clerical writers tainted with sexual immorality.

About Hugh's family background quite a bit is known. ${ }^{98}$ He was born around 885 towards the end of the Carolingian period, as were some of those writing about him. ${ }^{99}$ His maternal grandfather was Lothar II (d. 869), the Carolingian king who unsuccessfully tried to divorce his legitimate wife Theutberga in favour of Waldrada his first love. His mother Bertha (d. 925), daughter of Lothar and Waldrada, ${ }^{100}$ was a politically influential figure in Italy in her own right. ${ }^{101}$ Her brother Hugh (the king's uncle, after whom he was perhaps named) fought against Louis the Younger, ${ }^{102}$ and was blinded by Charles the Fat for having 'acted unwisely in the emperor's kingdom'. ${ }^{103}$ Bertha was first married to Theobald, count of Arles (Hugh's father) who is much less well-documented than his (Carolingian) wife. ${ }^{104} \mathrm{He}$ rebelled against Carolingian rule alongside his brother-in-law Hugh and in 880 was defeated by the combined forces of Louis the Younger and the sons of Louis the Stammerer, all of them Carolingians in the legitimate line. ${ }^{105}$ Hugh's paternal grandfather was Hubert (died c. 864), Theutberga's brother, who was of course accused of incest and sodomy with his sister by Lothar II's supporters during the divorce crisis, including Hincmar of Reims. He was also lay abbot of St Maurice d'Agaune in Burgundy and a political force to be reckoned with in that region. ${ }^{106}$ This side of his family has been termed 'Bosonids' by many historians and for one of those Hugh's success represented its 'highpoint'. ${ }^{107}$

Hugh's immediate ancestors therefore included the Carolingian Lothar II, both the women in the famous divorce case and their relatives, a conflicted background in Freudian 
terms a perspective which goes some way to explaining why Hugh's own marital and sexual relationships were to prove complex and controversial with contemporaries and later generations alike. ${ }^{108}$ The fact that Hugh's family history comprised some of the most controversial figures and events in the history of the Frankish kingdom must have weighed heavily on the young man most especially because uncompromising Carolingian sources, all of them written by hostile clerics, repeatedly blackened both sides of his family, not just one. Although Hugh's life is thus sparsely documented when compared to the most prominent Carolingian lives (such as Charlemagne, Louis the Pious and Charles Bald) it nevertheless provides a penetrating example of how textual representation conditions (or even determines) political history (and vice versa). Comparison of Hugh's charters with the majority of Flodoard's brief entries for the king suggests that he was a fairly typical late Carolingian ruler. However, that one reference to Hugh's bigamy opens up the possibility of deeper, authentic but not necessarily truthful, narratives which reveal more of Hugh's complex biography, including his motivations.

However, in order to get closer to Hugh as a person, only narratives written by those who knew the king will do. Flodoard did not know him, and Rather presents a narrow view of the king as an enemy who was once a friend. Liutprand of Cremona, although a younger contemporary of Hugh, wrote the fullest surviving narrative of him in his Antapodosis and he is the crucial witness (in part eye-witness) for Hugh's reign. ${ }^{109}$ One tenth-century manuscript (Munich, Bayerische Staatsbibliothek Clm 6388, written in Italy but soon acquired by Bishop Abraham of Freising) may be a copy corrected by Liutprand himself which has some claim to represent Liutprand's opinions directly to us, something very unusual among authors from this period. ${ }^{110}$ Liutprand's 'account' of Hugh is scattered through several books of his text and has been used rather selectively by historians to bolster their view that Hugh was a dissolute ruler whose abilities paled into insignificance alongside those of his Carolingian 
forebears and Ottonian contemporaries. While there is little dispute that Liutprand blackened Hugh's reputation and did it with some style, ${ }^{111}$ once this aspect of his work is read in detail a more complex picture emerges.

Liutprand worked on this book in the years 958-962 (as far as is known) which was at least ten years after Hugh had died. Necessarily, he had to look back at him and could forget as well as remember what he knew from his own and others' experience of the king. He carefully signalled his personal connection with Hugh in several parts of his book. First, he confided that he sang at Hugh's 'court' in Pavia as a boy soprano (c. 931) and that he was the best singer there. ${ }^{112}$ Second, he narrated how his father had served Hugh as ambassador to the Byzantine emperor Romanos I in 927 soon after he became king. ${ }^{113}$ Reporting his father's death shortly after the latter's return to Italy from this eastern trip Liutprand confided that he was left as 'a small boy' (parvulus). ${ }^{114}$ Although Liutprand does not reveal what happened to him at that point his father's death was surely a traumatic moment in his young life. It may be (we do not know) that from then on in the mind of the young Liutprand he lived at the court of the man who had in some ways 'killed' his own father. ${ }^{115}$ Third, Liutprand tells us that his step-father also subsequently acted as emissary for Hugh (5.24) in 941-4, which implies that Liutprand's mother had remarried (also traumatic?) and that the family continued to be trusted by the king. ${ }^{116}$

In Liutprand's version of his relationship with Hugh his autobiographical framing means that the rapid sketch of the king in Antapodosis III 19, although in literary terms a conventional portrait of a wise ruler as Roman and Carolingian authors writing biographically were accustomed to provide (cf. Livy, Suetonius, Einhard), might also have been taken from life especially as this passage was carefully corrected in the Freising manuscript:

'About the many virtues of King Hugh that lust undermined'. King Hugh was of no lesser wisdom than boldness, nor of smaller strength than craftiness, also a worshipper of God and a lover of those who love holy religion, solicitous for the needs of the poor, very caring towards churches; he not only loved 
but also deeply honoured religious and philosophical men. Hugh was a man, though, who even if he shone with virtues, besmirched them through his passion for women (trans. Squatriti, p. 118, slightly modified). ${ }^{117}$

This retrospective portrait is deliberately satirical in its contrast of virtus with luxuria, especially given what Liutprand as a man writing in his late 30s may have recalled of Hugh's imprisonment of Bishop Rather for treachery at Pavia between 935 and 937 when he himself had been around 16 years old and was probably also in Pavia. Liutprand argued here that Hugh's interventionist approach to the appointment of his non-Italian cronies to the major north Italian sees was very far from honouring 'religious and philosophical men' whereas Liutprand the deacon from Pavia writing as a prospective Ottonian bishop who saw himself as defender of correct canonical procedure in this regard, certainly honoured them in his text especially the traitorous Rather who, unlike Hugh, was still alive. ${ }^{118}$ Conrad Leyser's view that Liutprand's 'central topic' was bishops thus has some validity although it is not what Liutprand himself said he was doing (which was 'revenge' on kings). ${ }^{119}$

In the chapter which follows (III 20) Liutprand listed Hugh's many illicit sexual relationships and his various illegitimate children perhaps as a way of condemning both the Carolingian and the Bosonid inheritance in Italy and so raising his stock with his intended Ottonian audience as Philippe Buc has argued. ${ }^{120}$ In the same section he told his readers that Hugh's legitimate wife (a simple uxor) Alda was the mother of Lothar while a concubine Wandelmoda (albeit mulier nobilissima) was the mother of a son named Hubert. ${ }^{121}$ Two generations after the infamous divorce of Hugh's maternal grandfather Lothar II and the latter's rough treatment of his paternal grandfather Hubert Liutprand presented a parallel pairing of 'Lothar and Hubert' (again legitimate and illegitimate), boys whose names the king had surely bestowed while fully aware of their ancestry. It seems likely that Liutprand too was aware of the parallels and deliberately introduced them into contemporary political discourse. 
Elsewhere Liutprand presented Hugh and his relations with precision as foreigners who departed from local traditions of rule. He characterised Hugh's Carolingian mother Bertha as the dominant partner in her marriage with Adalbert of Tuscany, the young Hugh's step-father. ${ }^{122}$ She encouraged Adalbert to rebel against King Lambert (c. 880-898), ${ }^{123}$ the lost hope of the Italian kingdom, presented by Liutprand as the last 'good king' in the Carolingian tradition. Liutprand implies (incorrectly) that Bertha was still alive when Hugh came from Provence to Italy to 'take the kingship'. ${ }^{124}$ It was only afterwards that she died in his text. ${ }^{125}$ This presentation like that in Flodoard's Annals again plays up her role as kingmaker, an unsuitable role for women however well-connected in Liutprand's misogynistic world view but one which surely Bertha herself aimed at. ${ }^{126}$

Once Hugh had been formally constituted as king (III 21) Liutprand reported that he sent out embassies to obtain the amicitia of other rulers, especially the Saxon king Henry (III 22-24). He followed this (as was customary) with an embassy to Byzantium, the one apparently headed by Liutprand's unnamed father. It reached Emperor Romanos I in 927. After a successful visit, Liutprand's father died on his return. ${ }^{127}$ In addition to any psychological distress this caused Liutprand it also meant that Liutprand's family were very well connected at Hugh's court and had benefitted directly from Hugh's generosity, just like those people documented in the king's charters. At this point Liutprand and his parents could be regarded as part of Hugh's extended familia as Rather was also, 'new men' who Hugh so 'radically' employed to rule. By the time Hugh had decided to send his daughter Bertha ('Eudochia', d. 949) to Constantinople to try to marry her to the Emperor, she was accompanied not by Liutprand who was probably still too young for such an important mission, but by Bishop Sigifred of Parma who the charters reveal to have been one of Hugh's most trusted advisors. ${ }^{128}$ 
Liutprand's scrupulous narration of the events of Hugh's reign therefore pinpoints the importance of family and alliance to the king just as often and in similar ways as Hrotswitha does for the Ottonians in her Gesta Ottonis. Like Flodoard, the deacon of Pavia tells a story of networks and associations similar to those evidenced by the king's charters and obviously involving many of the same people but his interpretation of this story was more negative, an opinion based on personal malice at having failed to be promoted at court by the king as he had expected. Liutprand was not saying that using family as the basis of one's rule was bad, although given his beliefs he could not approve of non-marital sexual liaisons, for he was probably trying to follow in his father's footsteps with the king's patronage. But he could not cope with his dashed dreams of advancement: Liutprand's disappointment was Hugh's unforgiveable sin.

The sophisticated narratives of Rather, Flodoard and Liutprand establish that Hugh and his family were both written and talked about, and that such routine activities helped to form and perpetuate the social memory of the king in the immediate aftermath of his death. ${ }^{129}$ If none of the three was exactly an advocate for Hugh that is not so surprising given their personal circumstances. That no-one else was either, not the king himself, members of his close family or petitioners in charters is more difficult to explain if, as is the current view, Hugh really was successful. Why didn't they commission rival narratives which fostered and propagated a positive image of Hugh to ensure that his memory would be positive? That they did not is surely significant for it means that Hugh was abandoned by his friends as well as his enemies and consequently Hugh's enemies were at liberty to make the connection between Hugh's supposed moral failings (a dangerous combination of injustice and incontinence) and the ultimate failure of his rule in Italy.

Much like the king's political networks on the ground the surviving documentation can be divided into 'insiders' (the charters) and 'outsiders' (the rest). The 'outsiders' quite 
consciously chose either to present him as a failure or to forget him altogether. ${ }^{130}$ The forgetters included Hrotswitha of Gandersheim, who touched on Hugh's family in her Gesta Ottonis written in the 960s some fifteen years after Hugh had died. Her Ottonian narrative is well-known for having prioritised family politics over military campaigns which were more typical of the stories which male chroniclers largely favoured. ${ }^{131}$ Her images of kingship were nonetheless the very ones Rather had employed to castigate Hugh: Otto displayed wisdom, piety, justice, clemency and fortitude. ${ }^{132}$ Hugh and his family were introduced to her narrative only at the very end of their dynastic history at moment of Lothar's demise in 950 when, as Hrotswitha put it, Adelaide, future Ottonian, 'rightly' succeeded him. She juxtaposed Otto's legitimacy with a single reference to Hugh's illegitimacy: his forced expropriation of the Italian throne from Berengar. Although Hrotswitha, unlike her male contemporaries, did not deal with Hugh's irregular sexual relationships directly in her Otto-obsessed narrative she did present Hugh's acquisition of the Italian kingship in ambiguous language so that her readers could have understood it as rape (raptum violenter). ${ }^{133}$

Perhaps these 'narratives of failure', judgments which contemporaries passed on Hugonid rule in Italy, were both more accurate and more powerful than modern scholarship has suggested. Hugh's twenty-year long Italian adventure did indeed end unsuccessfully as his ineffectual son Lothar outlasted his father by only three years, to die poisoned by Berengar II, his father's nemesis. His young daughter Emma survived to marry a king of France (Louis) rather than a king of Italy. Although Hugh did, in fact, have a powerful and successful son Hubert, he was not legitimate and so could not be acceptable in clerical circles. Lothar's fate may well have coloured his father's reputation in the eyes of the select group of contemporaries whose work has formed the evidence for my argument, as for them a successful king was above all one who transmitted his power to an effective and necessarily 
legitimate son. It was not for nothing that Hugh was repeatedly described as sexually immoral during his life and after it had ended.

Importantly, our narrators were prepared to abandon their own 'rules' when it suited them politically and Liutprand played down Lothar's legitimacy in a presentation of Hugh's reign which, much like Archbishop Hincmar's devastating dismissal of his great-grandfather Lothar II, was deliberately framed as the master narrative. In his role as narrator of Hugh's destiny he wrote up the king's life at some length and in detail precisely so he could take his revenge upon him as well as on Berengar II, his main target. He was determined to destroy both their reputations (their fama) in part as a psychological act intended to make right the wrong Hugh had done to him by not rewarding the loyalty he had received from Liutprand's own father. Rather was equally vengeful even though he, unlike Liutprand, feigned grief at Hugh's death. For both authors the personal was political, in the actuality of their lives and their sense that Hugh had constrained them but also textually as their narratives were above all self-justificatory and self-revelatory. The political story they told was that Hugh made his family connections central to the institutions of government and he did it so well that he managed to survive as the effective king of Italy for nearly twenty years despite credible military challenges to his position. This could only have been possible because he had adopted a very broad concept of 'family' to secure a wide but at the same time personal network of supporters. Liutprand sneered at Hugh's four wives, five concubines and eight mostly bastard children but he must have known that sexual relationships of such kinds were the very stuff of successful kingship in his day. The political realities of his time, so well expressed by Hugh's own sexual history, may well have encouraged Hugh to ignore the hypocritical stance often adopted in texts authored by clerics and monks when they wrote about kings and queens in impossibly idealised Christian terms. Hugh understood that it was not possible to be a successful ruler by remaining sexually faithful to a single wife if that wife 
did not have a son who survived to adulthood. A more fecund rival would step in. In this sense Hugh's politics was personal too. Hugh's charters, from which some of his familial politics can be disinterred, in some ways function as a counter narrative to Liutprand's distorted tale of the king's dissolute reign, but close reading and comparison suggest that Liutprand is a more reliable narrator of the political realities of his age than is often believed.

While the ecclesiastics discussed here predictably criticised Hugh when his political actions went against the interests of their own church or of themselves their texts expressed, perhaps more profoundly, the powerlessness felt by their authors in a world where family connections mattered so very much. As clerics they could not, or at least were not supposed to by their own self-imposed rules, make use of their own family connections to further their own political ambitions in one crucial respect: they could not have biological children. Perhaps some clerics wanted to and may even have done so if the Veronese priests who opposed Rather by stating that they also were men with families who ought to be able to marry existed in reality outside the imagination of Rather himself. ${ }^{134}$ Unable to engage fully in political reality in the 'normal ways' some of them, above all Liutprand, chose to get their revenge personally and politically in polemical writing of some psychological penetration as autobiography, as biography and as history in ways that charters, however grand, could never achieve.

\footnotetext{
${ }^{1}$ I am grateful to Roberta Cimino and Edward Roberts who organized 'Politics and Texts in Late Carolingian Europe' (University of St Andrews, July 2013) for inviting me to speak at the conference and to all the participants for very stimulating discussions. The follow-up sessions at Leeds IMC in July 2014, organised by Levi Roach, were equally thoughtprovoking. I am indebted to Edward Roberts, Trish Skinner, Giacomo Vignodelli, the two anonymous reviewers and editors of the journal for their helpful comments on earlier written drafts. The views expressed are of course my own.
} 
${ }^{2}$ Jean-Pierre Poly, La Provence et la société feodale 879-1166 (Paris, 1976) termed Louis a 'shadow king' (p. 31). Louis, then king of Italy, had been blinded by Berengar of Ivrea in 905, who usurped him as Berengar I. Hugh married Louis' sister Willa and on taking over as the effective ruler of Provence he moved his capital from Vienne (where Louis continued to reside) to Arles. When Louis died in June 928 Hugh took over officially as king of Provence. See Constance Brittain Bouchard, 'Burgundy and Provence, 879-1032', in Tim Reuter (ed.), The New Cambridge Medieval History, volume III, c. c. 900-c.1024 (Cambridge, 1999), pp. 328-345 at pp. $340-41$.

${ }^{3}$ In 928 Flodoard of Reims reported that Hugh came to an agreement with Raoul, king of the Franks, whereby he ceded the County of Vienne to Heribert. This was 'in place of Hugh's own son Odo': S. Fanning and B. S. Bachrach (trans.), The Annals of Flodoard of Reims 919966 (Peterborough, Ontario, 2004), p. 18.

${ }^{4}$ He was, for example, in 924 allied with King Rudolf of Burgundy against the Magyars who had recently attacked the Italian capital of Pavia, a traumatic event which brought about the death of Berengar I at the hands 'of his own people' (Fanning and Bachrach, Annals of Flodoard, p. 11).

${ }^{5}$ Willa, Alda, Marozia (disputed), and Bertha.

${ }^{6}$ The distinction between marriage and concubinage is explained by Pauline Stafford, Queens, Concubines and Dowagers. The King's Wife in the Early Middle Ages (London, $2^{\text {nd }}$ edn. 1998), pp. 62-71 and Ruth Mazo Karras, Unmarriages. Women, Men, and Sexual Unions 
in the Middle Ages (Philadelphia, 2012), especially in her chapter on 'unequal unions' (pp. 68-114). In Hugh's case his less formal unions came about later in life.

${ }^{7}$ Lothar and Alda were the legitimate ones. The others, including Hubert, Boso and Bertha, were illegitimate.

${ }^{8}$ M. Marrocchi, 'Lotario II, Re d'Italia', DBI IX, pp. 29-31, states that he was born in 930 but the evidence is inconclusive and he may already have been as old as five when he became coking. This was Hugh's way of signalling his dynastic intentions in Italy.

${ }^{9}$ Luigi Schiaparelli (ed.), I diplomi di Ugo e Lotario, e di Berengario ed Adalberto (Rome, 1924), p. 56 (doc. 20, 12 March 929). Berengar petitioned here in favour of the ancient monastery of San Pietro in Ciel d'Oro in Pavia which sought confirmation of previous diplomas, its immunity and local fishing rights.

${ }^{10} \mathrm{He}$ had previously been challenged by Berengar in the spring of 945 , and temporarily vacated Italy then: Antap. V 26-28. Two diplomas were issued by Lothar alone in April and May 945 (Schiaparelli (ed.), I diplomi di Ugo e Lotario, docs 80 (13 April, in favour of Riprando) and Loth. 1 (27 May, in favour of the church of Mantua and granting the bishop the right to produce coinage).

${ }^{11}$ Flodoard cited poison (Fanning and Bachrach, Annals of Flodoard, p. 55). Hrotswitha (Gesta ottonis lines 467-8) opted for disease. Liutprand of Cremona did not mention his death in his Antapodosis. 
${ }^{12}$ Giuseppe Sergi, 'The Kingdom of Italy', in Reuter (ed.), NCMH III, pp. 346-71 at pp. 35560.

13 'who is still alive and now is a mighty prince (princeps potens) of the Tuscan province, whose deeds (acta), God willing will be explained in the appropriate place', Liudprand of Cremona, Antapodosis I.20 (English translation by Paolo Squatriti, The Complete Works of Liudprand of Cremona (Washington D.C., 2007), p. 118; Paolo Chiesa (ed.), Liudprandi cremonensis opera omnia, Corpus Christianorum Continuatio Mediaevalis CLVI (Turnhout, 1998), pp. 75-76). He was the child of the noblewoman Wandelmoda.

${ }^{14}$ The nature of tenth-century kingship is evidently a large and now much-studied subject. The literature is too large to survey here. The best way in (at least in English) is perhaps provided by Janet L. Nelson, 'Rulers and government', in Reuter (ed.), NCMH III, pp. 95129. The topics of 'ritual' and friendship have dominated discussion for many years on which see, among many, Karl Leyser, 'Ritual, Ceremony and Gesture: Ottonian Germany’, in K. Leyser, Communications and Power in Medieval Europe, The Carolingian and Ottonian Centuries, ed. T. Reuter (London, 1994), pp. 187-213'; Gerd Althoff, Family, friends and followers : political and social bonds in Medieval Europe, English trans. C. Carroll (Cambridge, 2004) and his Otto III, English trans. Phyllis G. Jestice (Pennsylvania, 2003), pp. 132-45. Philippe Buc's critique of this approach developed at length in his book The Dangers of Ritual. Between Early Medieval Texts and Social Scientific Theory (Princeton, 2001) has been thoroughly debated e.g. Geoffrey Koziol, 'The Dangers of Polemic: Is Ritual still an interesting topic of historical study?', Early Medieval Europe 11.4 (2002), pp. 367-88 
and Philippe Buc, 'The monster and the critics: a ritual reply', Early Medieval Europe 15.4 (2007), pp. 441-452.

${ }^{15}$ Patrick J. Geary, Phantoms of Remembrance. Memory and Oblivion at the End of the First Millennium (Princeton, 1994), pp. 135-46 at p. 135.

${ }^{16}$ Chris Wickham, The Inheritance of Rome. A History of Europe from 400 to 1000 (London, 2009), p. 437, and earlier in Early Medieval Italy (Basingstoke, 1981), pp. 177-83.

17 Sergi, 'Kingdom of Italy', p. 354. Italian historiography of this period has tended to focus on institutions and their collapse, the best example being the work of Giovanni Tabacco (e.g. Egemonie sociali e strutture del potere nel medioevo italiano [Turin, $2^{\text {nd }}$ edn 1979], pp. 18921). He implied (p. 190) that Hugh's use of 'new men', largely Provencal and related by blood, blurred existing distinctions between the institution of the kingdom with its ideas of office and service and the king's more personal sphere of influence.

${ }^{18}$ Luigi Schiaparelli, 'I diplomi dei re d'Italia. Ricerche storico-diplomatiche, 5: i diplomi di Ugo e di Lotario', Bollettino dell'Istituto Storico Italiano 34 (1914), pp. 7-255 and Luigi Schiaparelli (ed.), I diplomi di Ugo e Lotario, e di Berengario ed Adalberto (Rome, 1924). A fine study has recently appeared which reveals the huge potential of this material: Giacomo Vignodelli, 'Berta e Adelaide: la politica di consolidamento del potere regio di Ugo di Arles', Reti Medievali Rivista 13 (2012), pp. 247-94. I hope to produce a study of Hugh's charters which takes full account of Koziol's methodology at later date.

${ }^{19}$ Schiaparelli (ed.), I diplomi di Ugo e Lotario, doc. 1, confirming the property of the church of San Zeno di Verona. The petitioners were the local bishops Notker of Verona (d. August 
928) and Adalbert of Bergamo (d. 935). His powerful mother Bertha had died in 925: Patricia Skinner, Women in Medieval Italian Society 500-1200 (Harlow, 2001), p. 102 (with an English translation of her epitaph).

${ }^{20}$ What is known about Hugh's death is set out at http://sepolture.storia.unipd.it/index.php?page=scheda\&id=58 ('Le sepolture regie del regno italico, secoli VI-X', a project by Piero Majocchi and Cristina La Rocca at the University of Padua which has documented all known dates and places of burials for early medieval kings in Italy).

${ }^{21}$ Twenty seven diplomas (11 originals; $40.7 \%$ of this total) were issued between 926 and October 931, when Hugh began to rule jointly with his young son Lothar. As joint-kings Hugh and Lothar issued between 931 and 947 a further 50 (28 originals; 56\% of this total), and Lothar issued 16 alone (11 originals; $68.5 \%$ of this total). There are significant clusters in 926, 929 and 945. By comparison, for the thirty-six year reign of Berengar I (888-924, but with significant interruptions by rival claimants) there are 140 texts (73 originals, 52\%), whereas there are only 16 diplomas for Berengar II's ten-year reign (951-961) and 3 for Adalbert's two years (960-961), although the periodic interventions of Otto I in Italian affairs have to be borne in mind during this period.

${ }^{22}$ Liutprand reported that as soon as Hugh was king 'like a prudent man he began to send his messengers everywhere throughout all lands and to seek the friendship (amicitia) of many kings and princes, especially the very famous King Henry' (Antap. III 21), discussed by Germana Gandino, Il vocabolario politico e sociale di Liutprando di Cremona (Roma, 1995), pp. $135-43$. 
${ }^{23} \mathrm{He}$ appeared in 928, 929, 931, 932, 933, 939, 941 and 943, acting favour of the churches of Santa Maria di Parma (928); Trieste (929); Sant'Antonino di Piacenza (931); nunnery of Santa Maria Theodota, Pavia (932); SS. Fiora e Lucilla, Arezzo (933); SS. Martini e Leoni, Pavia (939); S. Benedetto, Subiaco (941); and the episcopal church of Pavia (943). As can be seen these beneficiaries are spread throughout the regnum. As might be expected of the king's close advisor (consiliaris in doc. 27, 17 April 931), he petitioned on behalf of churches in Pavia, the capital and focus for court life in this period. He accompanied Hugh's daughter Bertha to Constantinople to secure her marriage with the emperor's son (see below nt. X). Sigifred died late in 944 or early in 945: Jean-Charles Picard, Le souvenir des évêques. Sépultures, listes épiscopales et culte des évêques en Italian du Nord des origins au $X^{e}$ siècle (Rome, 1988), p. 366.

${ }^{24}$ Alda appeared in 927 (her name in majuscule and designated as consors), 929, 930, 931 and 932, acting in favour of Tetgrimo (compatri et fidelis) and his nunnery S. Salvatore di Agna (927) and the see of Parma (929, 930, 931 and 932). Berengar appeared in 929, 945 (twice), 947 and 948, acting in favour of S. Pietro in Ciel d'Oro, Pavia (929); canons of Vercelli (945); church of Mantua (945); S. Giovanni Domnarum (947); and Count Manfred (948). Both figure in narrative accounts.

${ }^{25}$ Ermengard appeared in 926, 930, 931 and 932, acting in favour of the nunnery of S. Sisto, Piacenza (926) and the church of Parma (930, 931, 932). Liutprand was particularly unpleasant with regard to her. Bishop Ambrose appeared in 940, 942 (twice) and 945 acting in favour of Count Aleramus (940); the church of Padua (942); the church of Reggio-Emilia (942); the church of SS. Antonino e Giustina, Piacenza (945). 
${ }^{26}$ Church of Parma $(926,929,930$ x 2, 932, 936); Borgo S. Donnino, S. Maria di Parma (928); Canons S. Maria, Parma (935, 944); Bishop of Parma (935).

${ }^{27}$ S. Sisto, Piacenza, the church of Asti, and SS. Antonino and Giustina in Piacenza (all in 926).

${ }^{28}$ Church of Parma $(929,930)$; nunnery of S. Maria di Theodota, Pavia (932). This man had been an ally of King Rudolf and count of the palace at Pavia (Antap. II 61-64, III 39). Samson (Antap. III 41 praepotens comes) was a supporter of Hugh in the rebellion of Gezo and Walpert, judges of Pavia, against him early in his reign. He had, like Giselbert, previously been an ally of King Rudolf, to whom he gave the famous holy lance which ended up in the Ottonian treasury (Antap. IV 25). He was one of those magnates accused by the author of the Miracles of St Columbanus for having appropriated monastic property (Alexander O'Hara and Faye Taylor, 'Aristocratic and monastic conflict in tenth-century Italy: the case of Bobbio and the Miracula Sancti Columbani', Viator, 44/3 (2013), pp. 4362at pp. 49-9 with references).

${ }^{29}$ Church of Aquileia (931); S. Martino, Lucca (932); S. Donato, Arezzo (933). This Boso, given his name, may have been a relative of Hugh's, probably his brother who ruled in the Tuscan march: Antap. III 47 and IV 11-12 (one of Liutprand's more distasteful stories aimed at Boso's wife Willa).

${ }^{30}$ Count Milo (941); Bernard, fidelis (943, twice). 
${ }^{31}$ Canons of Reggio-Emilia (943); church of Pavia (943); SS. Antonino e Giustina, Piacenza (945). Elisardo (Eduard Hlawitschka, Franken, Alemannen, Bayern und Burgunder 774-962 (Freibrug im Breisgau, 1960), pp. 175-6) was married to Rotlinda, illegitimate daughter of Hugh, as a reference to him as beneficiary with her and Countess Rotruda que Roza vocatur in a diploma of 29 March 945 (doc. 79) shows. The latter may have been the same 'Roza' who Liutprand reported was Count Giselbertus (Antap. III 39) and latter, according to him at least, became one of Hugh's concubines Giselbertus (Antap. IV 14).

${ }^{32}$ Guy: Church of Aquileia (931); ex-empress Anna (936, the former wife of Berengar I). Atto: canons of Piacenza (948); church of Trieste (950). Guy was one of the main targets of the Bobbio monks in the dispute of 929 as recorded in the Miracles of St Columbanus (O’Hara and Taylor, 'Aristocratic and monastic conflict', pp. 49, 54, 59).

${ }^{33}$ See note $X$ above.

${ }^{34}$ Herwig Wolfram, 'Political theory and narrative in charters', Viator, 26 (1995), pp. 39-51 to be compared with Hagen Keller, 'The Privilege in the public interaction of the exercise of power: forms of symbolic communication beyond the text', in Marco Mostert and P. S. Barnwell (eds), Medieval Legal Process. Physical, Spoken and Written Performance in the Middle Ages (Turnhout, 2011), pp. 75-108 at pp. 78-80 (with references to the extensive literature).

${ }^{35}$ Schiaparelli, I diplomi di Ugo e Lotario, doc. 17 at p. 49. 
${ }^{36}$ Document 16 as well as 17 . Schiaparelli argued that many of the earlier charters were drafted in Provence by Hugh's chancery there by his faithful chancellor Gerlan.

${ }^{37}$ Silvana Patriarca, 'Indolence and Regeneration: Tropes and Tensions of Risorgimento Patriotism', American Historical Review 110 (2005), 380-408 at p. 384.

${ }^{38}$ Jon N. Sutherland, Liudprand of Cremona, Bishop, Diplomat, Historian (Spoleto, 1988), p. 78. The exact date is uncertain. His first surviving charter as bishop is dated 14 January 962 so his accession had definitely happened by then.

${ }^{39}$ Ross Balzaretti, 'Men and Sex in Tenth-century Italy'; Skinner, Women in Medieval Italian Society, pp. 99-111; Balzaretti, 'Liutprand of Cremona's Sense of Humour'.

${ }^{40}$ Authoritatively discussed by Sarah Hamilton, 'Inquiring into adultery and other wicked deeds: episcopal justice in tenth- and early eleventh-century Italy', Viator, 41 (2010), pp. 2144.

${ }^{41}$ Jason Glenn, 'Political history', in C. Chazelle and Felice Lifshitz (eds), Paradigms and Methods in Early Medieval Studies (New York, 2007), pp. 153-68 at p. 164.

${ }^{42}$ Atto of Vercelli (d. 960) could be added to this list. His difficult Perpendiculum ('plumb line' in English) is a heavily-coded attack on Hugh: see Giacomo Vignodelli, Il filo a piombo. Il Perpendiculum di Attone di Vercelli e la storia politica del regno italico (Spoleto, 2011) and in the article published above. 
${ }^{43}$ Elizabeth Tyler and Ross Balzaretti (eds), Narrative and History in the Early Medieval West (Turnhout, 2006), pp. 1-3.

${ }^{44}$ Conrad Leyser, 'Episcopal office in the Italy of Liudprand of Cremona, c. 890-c. 970', English Historical Review, 125 (2010), pp. 795-817 at p. 798 refers to 'a brilliantly selfpromotional group of clerics [who] seized the chance to advance their own careers...'.

45 O'Hara and Taylor, 'Aristocratic and monastic conflict in tenth-century Italy', p. 58.

${ }^{46}$ Felice Lifshitz, 'Beyond positivism and genre: "hagiographic” texts as historical narrative', Viator 25 (1994), 95-113.

${ }^{47}$ David R. Bates, Julia Crick and Sarah Hamilton (eds), Writing Medieval Biography, 7501250. Essays in Honour of Professor Frank Barlow (Woodbridge, 2006).

${ }^{48}$ Philippe Buc, 'Italian Hussies and German Matrons. Liutprand of Cremona on Dynastic Legitimacy’, Frümittelalterliche Studien 29 (1995), pp. 207-25.

${ }^{49}$ Geoffrey Koziol, The Politics of Memory and Identity in Carolingian Royal Diplomas. The West Frankish Kingdom (840-987) (Turnhout, 2012).

${ }^{50}$ Colin Morris, The Discovery of the Individual: 1050-1200 (London, 1972), although things have moved on since. 
${ }^{51}$ Janet L. Nelson, 'Writing early medieval biography', History Workshop Journal 50 (2000), pp. 129-36; Jay Rubenstein, 'Biography and autobiography in the Middle Ages', in Nancy Partner (ed.), Writing Medieval History (London, 2005), pp. 22-41.

${ }^{52}$ For example, Cronaca di Novalesa V 3 (ed. Alessio), pp. 254-59.

${ }^{53}$ Simon MacLean, 'Insinuation, Censorship and the Struggle for Late Carolingian Lotharingia in Regino of Prüm's Chronicle', English Historical Review, 104 (2009), pp. 1-28 at p. 1 .

${ }^{54}$ Tim Reuter, Medieval Polities and Modern Mentalities (Cambridge, 2006), p. 99.

${ }^{55}$ Heinrich Fichtenau, Living in the Tenth Century. Mentalities and Social Orders, trans. P. J. Geary (Chicago, 1991), pp. 166-70.

${ }^{56}$ Karl Leyser, 'Ritual, Ceremony and Gesture: Ottonian Germany', in Communications and Power in Medieval Europe. The Carolingian and Ottonian Centuries, p. 194 stressed that their distance from Carolingian traditions helped to develop them into a coherent group of writers.

${ }^{57}$ Geary, Phantoms of Memory, pp. 3-30.

${ }^{58}$ Peter L. D. Reid (ed.), Ratherii Veronensiis, Praeloquiorum Libri VI, CCCM XLVI A (Turnhout, 1984), pp. 3-196, English trans. Reid, The Complete Works of Rather of Verona (Binghampton, New York, 1991), pp. 93-155. Giacomo Vignodelli, 'Il problema della 
regalità nei Praeloquia di Raterio di Verona', in Giovanni Isabella (ed.), “C'era una volta un re...". Aspetti e momenti della regalità (Bologna, 2005), pp. 59-73. Mark F. Williams, 'Rather of Verona and the rhetoric of well-ordered friendship as exemplified in the Praeloquia', in J. Haseldine (ed.), Friendship in Medieval Europe (Stroud, 1999), pp. 213226 argues that Rather's view of friendship had more emotional warmth than usually thought.

${ }^{59}$ Praeloquia, III 5 (ed. Reid, pp. 80-81; trans. Reid, p. 97) in a passage quoting Matthew 22.12 ('Render to Caesar what is Caesar's and to God what is God's) and Wisdom 8.7 ('For he teaches temperance and wisdom and justice and virtue, than which nothing on earth is more useful to men').

${ }^{60}$ Mayke de Jong, The Penitential State. Authority and Atonement in the Age of Louis the Pious, 814-840 (Cambridge, 2009), pp. 5, 179-81 and Rachel Stone, Morality and Masculinity in the Carolingian Empire (Cambridge, 2012), pp. 332-34 on correctio and admonitio as concerns of kings. For Rather's rather Carolingian view that bishops should deal with sexual sins see Hamilton, 'Inquiring into adultery', pp. 31-33.

${ }^{61}$ Reid, Complete Works of Rather, p. 98.

${ }^{62}$ Reid, Complete Works of Rather, p. 107.

${ }^{63}$ Reid, Complete Works of Rather, p. 111.

${ }^{64}$ Ross Balzaretti, 'Men and sex in tenth-century Italy', pp. 145-51; Irene van Renswoude, 'The sincerity of fiction. Rather and the quest for self-knowledge', in R. Corradini, M. Gillis, 
R. McKitterick and I. van Renswoude (eds), Ego Trouble. Authors and their Identities in the Early Middle Ages (Vienna, 2010), pp. 227-242.

${ }^{65}$ Reid, Complete Works of Rather, pp. 223-29. Rather's letter collection is a good example of 'episcopal self-consciousness on the part of its author and his correspondents' (Sarah Hamilton, Church and People in the Medieval West [Harlow, 2013], p. 90).

${ }^{66}$ Otto had married Lothar's widow Adelheid at this time. They had to contend with the rebellion of Otto's son Liudolf and his brother-in-law Conrad who were trying to unseat Berengar who was supported by Otto, Adelheid (Conrad's sister) and Henry of Bavaria (Otto's brother): Karl Leyser, Rule and Conflict in an Early Medieval Society (London, 1979), p. 20. Flodoard reports their marriage in Pavia as his last but one entry for 951 (Fanning and Bachrach, Annals of Flodoard, p. 56).

${ }^{67}$ qui me tunc oppido, ut credebatur, dilegebat (ed. Weigle, Die Briefe des Bischofs Rather von Verona, p. 35), trans. Reid, Complete Works of Rather, p. 224.

${ }^{68}$ Weigle, Briefe des Bischofs Rather, p. 35; Reid, Complete Works of Rather, p. 225. 'Garafridus' is possibly Hugh's son Gotefredus who became Abbot of Nonantola in 947 (G. Waitz [ed.], Scriptores rerum langobardicarum et italicarum saec. vi-ix [Hannover, 1878], p. 572, reported by an eleventh-century text from Montecassino).

${ }^{69}$ Displicuit hoc non parum regi contraria molienti (Weigle, Briefe des Bischofs Rather, $\mathrm{p}$. 36; Reid, Complete Works of Rather, p. 225). How he knew what the king was planning is unclear. 
${ }^{70}$ Royal anger continued to be outside the Christian tradition in this period in which the merciful qualities of kings were praised: Gerd Althoff, 'Ira regis: prolegomena to a history of royal anger', in Barbara Rosenwein (ed.), Anger's Past. The Social Uses of an Emotion in the Middle Ages (Ithaca and London, 1998), pp. 59-74 at p. 66. This means that Rather's depiction of Hugh's fury was yet another way to undermine his kingship.

${ }^{71}$ Reid, p. 225. Rather believed that it was Hilduin who had betrayed him to Hugh (Praeloquia 3.27), accusing him of treason having agreed along with Count Milo of Verona to invite Arnulf of Bavaria to take the Italian throne from Hugh. Liutprand, writing at the end of the 950s, certainly reported Rather's complicity (Antap. III 49-52).

${ }^{72}$ Praeloquia, 4.26 (Reid, Complete Works of Rather, p. 146).

${ }^{73}$ François Bougard, 'Manasse', DBI 68 (2007) and Leyser, 'Episcopal office', pp. 808-10. Manasses had been appointed by Berengar not Hugh or Lothar.

${ }^{74}$ Weigle, Briefe des Bischofs Rather, p. 37; Reid, Complete Works of Rather, p. 226. Liutprand (Antap. III 49-52, V 27) conveyed well Milo's ambiguous stance towards Hugh. When he eventually rebelled against the king Liutprand reported rather cryptically that "no infidelity divided him from Hugh, but instead he suffered several damaging decisions from the king' (nulla hunc infidelitas ab Hugone divisit, verum illata sibi ab eodem nonnulla incommoda, ed. Chiesa, p. 139). Milo's life is outlined by Hlawitschka, Franken, Alemannen, Bayern und Burgunder, pp. 237-40.

${ }^{75}$ Weigle, Briefe des Bischofs Rather, p. 41; Reid, Complete Works of Rather, p. 228. 
${ }^{76}$ Thelma Fenster and Daniel Lord Smail (eds), Fama. The Politics of Talk and Reputation in Medieval Europe (Cornell University Press: Ithaca and London, 2000), 1-11, 210-14 and Chris Wickham, 'Gossip and resistance among the medieval peasantry', Past \& Present, 160 (1998), pp. 3-24.

77 Tyler and Balzaretti, 'Introduction', in Tyler and Balzaretti (eds), Narrative and History, pp. 3-4; Jason Glenn, Politics and History in the Tenth Century. The World and Work of Richer of Reims (Cambridge, 2004), pp. 9-12; Matthew Kempshall, Rhetoric and the writing of history (Manchester and New York, 2011). Simon MacLean, History and Politics in Late Carolingian and Ottonian Europe. The Chronicle of Regino of Prüm and Adalbert of Magdeburg (Manchester, 2009), p. 17 stresses that histories in this period were written above all to admonish rulers, as exemplified by Stuart Airlie, "'Sad stories of the death of kings": Narrative patterns and structures of authority in Regino of Prüm's Chronicle', in Tyler and Balzaretti, Narrative and History, pp. 105-131.

${ }^{78}$ As in the model study of Germana Gandino, Il vocabolario politico e sociale di Liutprando di Cremona (Rome, 1995).

${ }^{79}$ Kempshall, Rhetoric and the writing of history, pp. 285-86. This was, for some, a practice they had adopted after reading Roman historians. Although the use of the phrase implied doubt as to the truthfulness of the thing or event described the record of something documented by gossip still functioned as a record legitimised by writing. 
${ }^{80}$ Michel Sot, Un historien et son église. Flodoard de Reims (Paris, 1993) and recently

Edward Roberts, 'Flodoard, the will of St Remigius and the see of Reims in the tenth century', Early Medieval Europe 22 (2014), pp. 201-230. There is a useful sketch in Glenn, Politics and History in the Tenth Century, pp. 171-75.

${ }^{81}$ He may have encountered Hugh in 924 when with Archbishop Seulfus of Reims he attended a meeting where Hugh was present (Fanning and Bachrach, Annals of Flodoard, p. ix). He knew something about Vienne, Hugh's stronghold in Provence, which is covered in entries for 928, 931, 933 and 941.

${ }^{82}$ Philippe Lauer (ed.), Les annales de Flodoard publiées d'après les manuscrites (Paris, 1905). Eng. trans. by Steven Fanning and Bernard S. Bachrach, The Annals of Flodoard of Reims, 919-966 (Peterborough, Ontario, 2004). Claudio Leonardi, 'Intellectual life', in Reuter (ed.), NCMH III, pp.186-211 judged that Flodoard's writing tended 'more towards the narrative than towards the documentary' (p. 205). Hugh was noticed by Flodoard in his entries for $924,926,928,933,936,942,945$ and 946 , which is quite a substantial number from before he became Italian king until near the end of his rule.

${ }^{83}$ According to Folcuin of Lobbes (Gesta Abbatum Laubiensium, ch. 20, MGH SS 4, ed. G. H. Pertz, p. 64), Rather had sent a copy of his Praeloquia to Flodoard. He also reported (Ch. 19, p. 63) the flight of Hilduin and Rather to Hugh and Rather's first expulsion from Verona, seemingly based on his reading of Rather's own account. Flodoard himself had been to Rome.

${ }^{84}$ Cf. Liutprand, Antapodosis, III 9-10. 
${ }^{85}$ Trans. Fanning and Bachrach, Annals of Flodoard, pp 15-16. Hugo, filius Bertae, rex Romae super Italiam constituitur,expulso Rodulfo Cisalpinae Galliae rege qui regnum illud pervaserat et alteri feminae, vivente uxore sua, se copulaverat, occiso quoque a filiis Bertae Burchardo, Alamannorum principe, ipsius Rodulfi socero, qui Alpes cum ipso transmearat Italiae regni recuperandi gratia genero (Lauer (ed.), Les annales de Flodoard, p. 35).

${ }^{86}$ Discussing the example of Marozia, Patricia Skinner has argued that 'every mother's aim...was to see her own child ascend to rulership' (Women in Medieval Italian Society, $\mathrm{p}$. 106).

${ }^{87}$ Fanning and Bachrach, Annals of Flodoard, p. 17.

${ }^{88}$ Fanning and Bachrach, Annals of Flodoard, pp. 23 (Alberic, son of Marozia, held Rome against Hugh), 36 (Abbot Odo of Cluny tried to make peace between Alberic and Hugh; Hugh tried to drive the Arabs out of Frexinet), 42 (Hugh ousted as king) and 44 (peace was achieved and Hugh restored). Cf. Liutprand, Antapodosis V 28. Rosenwein, Negotiating Space, pp. 157-58 shows that Hugh and Lothar's only donation to Cluny in 934 was provoked by these events in Rome. Chris Wickham, Roma medievale. Crisi e stabilità di una città 900-1050 (Rome, 2013) is now essential for the Theophylact family.

${ }^{89}$ He noted the deaths of Berengar I (924) and Rudolf of Burgundy (937), as well as Lothar (950). 
${ }^{90}$ Berengarius quidam princeps Italiae, veneno ut ferunt necato Lothario rege, Hugonis filio, rex efficitur Italiae (Lauer (ed.), Les annales de Flodoard, p. 128 and Fanning and Bachrach, Annals of Flodoard, p. 55).

${ }^{91}$ Stuart Airlie, 'Private bodies and the body politic in the divorce case of Lothar II', Past \& Present, 161 (1998), pp. 3-38.

${ }^{92}$ De Jong, The Penitential State, pp. 185-213.

${ }^{93}$ Stone, Morality and Masculinity in the Carolingian Empire, pp. 298-310.

${ }^{94}$ Simon MacLean, Kingship and Politics in the Late Ninth Century. Charles the Fat and the End of the Carolingian Empire (Cambridge, 2003), 169-77.

${ }^{95}$ Timothy Reuter, 'Sex, lies and oath-helpers: the trial of Queen Uota', in Medieval Polities and Modern Mentalities, pp. 217-230.

${ }^{96}$ Balzaretti, 'Men and Sex in Tenth-century Italy', in Dawn Hadley (ed.), Masculinity in Medieval Europe (Harlow, 1999), pp.143-159 and Balzaretti, 'Liutprand of Cremona's Sense of Humour', in Guy Halsall (ed.), Humour, History and Politics in the Early Medieval West (Cambridge, 2002), pp.114-128.

${ }^{97}$ Perhaps Flodoard had read Hincmar's treatise on the divorce to which he presumably had access at Reims: Rosamond McKitterick, 'The Carolingian Kings and the See of Rheims, 
882-987', in Patrick Wormald, Donald Bullough and Roger Collins (eds), Ideal and Reality in Frankish and Anglo-Saxon Society (Oxford, 1983), pp. 228-250.

${ }^{98}$ Constance B. Bouchard, 'The Bosonids or Rising to Power in the Late Carolingian Age', French Historical Studies, 15 (1988), pp. 407-431 at pp. 416-20.

${ }^{99}$ Flodoard was born c. 893-94. Atto of Vercelli and Ratherius of Verona were both born earlier in the later 880s, and Liutprand and Hrotswitha were born later, respectively c.920 and c.935. As Hugh did not die until 948 all of these writers, apart from Hrotswitha, had knowledge of the king as adults, especially Ratherius who surely knew him personally.

${ }^{100}$ Karl Heidecker, The Divorce of Lothar II. Christian Marriage and Political Power in the Carolingian World (Cornell UP, Ithaca and London: 2010), pp. 184-6.

${ }^{101}$ Skinner, Women in Medieval Italian Society, pp. 100-104; Catia Renzi Rizzo, 'I rapporti diplomatici fra il re Ugo di Provenza e il califfo ‘Abd ar-Ramân III: fonti cristiane e fonti arabi a confronto', Reti Medievali Rivista 3.2 (2002); Tiziana Lazzari, 'La rappresentazione dei legami di parentela e il ruolo delle donne nell'alta aristocrazia del Regno italico (secc. IXX): l'esempio di Berta di Toscana', in C. La Rocca (ed.), Agire da Donna (Brepols, Turnhout: 2007), pp. 129-150; Germana Gandino, 'Aspirare al regno: Berta di Toscana', in La Rocca (ed.), Agire da Donna, pp. 249-268.

${ }^{102}$ AF 879-80 (trans. Reuter, pp. 85-91). For the details of the revolt see Simon MacLean, Kingship and Politics, pp. 149-53 and 'The Carolingian response to the revolt of Boso, 87987', EME 10 (2001), pp. 21-48. 
${ }^{103}$ AF 885 (trans. Reuter, pp. 97-99). That the annalist thought this was completely justified is shown by Geneviève Bührer-Thierry, “Just anger" or "Vengeful anger"? The punishment of blinding in the early medieval west', in B. Rosenwein (ed.), Anger's Past, p. 90.

${ }^{104} A B 880$ (trans. Nelson, p. 221).

${ }^{105}$ Regino, Chronicle s. a. 883 (trans. MacLean, p. 189).

${ }^{106}$ Regino, Chronicle, s. a. 855 (Simon MacLean (trans.), History and Politics in Late Carolingian and Ottonian Europe, p. 135).

${ }^{107}$ Bouchard, 'The Bosonids', p. 418. Geary, Phantoms of Remembrance, p. 139 and Buc, 'Italian Hussies' (p. 208) term them 'Hugonids'. We have to be cautious about these terms as they may impute a degree of self-consciousness about family and lineage which these people may not with certainty have possessed.

108 Jinty Nelson has suggested that the marriage of Theobald and Bertha may have healed the wounds opened by the divorce case in the interests of maintaining the political unit of Lotharingia ( $A B$ trans. Nelson, p. 221 n. 6). Constance Bouchard ('The Bosonids', p. 418) argued that 'practical considerations clearly overrode any personal considerations' in this match. While both these views are clearly possible explanations for the politics, it is hard to see how the emotional wounds could have been quite so easily healed. In general, see the thought-provoking arguments of Nancy Partner, 'The hidden self: psychoanalysis and the textual unconscious', in N. Partner (ed.), Writing Medieval History (London, 2005), pp. $42-$ 64. 
${ }^{109}$ Paolo Chiesa (ed.), Liudprandi cremonensis opera omnia, Corpus Christianorum Continuatio Mediaevalis CLVI (Turnhout, 1998), pp. 1-150; English translation by Paolo Squatriti, The Complete Works of Liudprand of Cremona (Washington D.C., 2007), pp. 41202. For an assessment of Squatriti's translation see Ross Balzaretti, 'Review article:

Liutprand of Cremona', Nottingham Medieval Studies 52 (2008), pp. 246-256.

${ }^{110}$ Paolo Chiesa, Liutprando di Cremona e il codice di Frisinga Clm 6388 (Turnhout, 1994).

The manuscript is digitised at: http://daten.digitale-

sammlungen.de/ db/bsb00006691/images/

${ }^{111}$ Philippe Buc, 'Italian Hussies and German Matrons. Liutprand of Cremona on Dynastic Legitimacy', Frümittelalterliche Studien 29 (1995), pp. 207-25 at p. 208, and especially The Dangers of Ritual, pp. 15-50.

${ }^{112}$ Antap. IV.1 (Chiesa, p. 97; trans. Squatriti, p. 141). It is hard to see why this made him Hugh's 'chaplain' (Buc, 'Italian Hussies', p. 208).

${ }^{113}$ Examined by Catia Renzi Rizzo (note X above).

${ }^{114}$ Antap. III 24.

${ }^{115}$ He probably could have observed Hugh closely at the very least on those occasions when we know the king was in Pavia: September 926, November 926, February 927, May 928, March 929, July 929, August 929, April 931. Schiaparelli, 'I diploma dei re d'Italia', pp. 727. 
${ }^{116}$ Eventually they shifted allegiance to Berengar: Tanta haec Berengarii fama, humanitate, liberalitate parentes mei acciti ei me ad serviendum tradunt; cui et inmensis oblatis muneribus secretorum eius conscium ac epistolarum constituent signatorum (Antapodosis, ed. Chiesa, p. 141). 'My parents, struck by Berengar's great reputation, by his humanity, by his generosity, handed me over to him for service; and having donated immense gifts to him, they made me his private adviser and the signatory of his letters' (Antap. V 30, trans. Squatriti, p. 192).

${ }^{117}$ De plurimis Hugonis regis virtutibus, quas luxuria foedabat. Fuit autem rex Hugo non minoris scientiae quam audatiae, nec infirmioris fortitudinis quam calliditatis; Dei etiam cultor sanctaeque religionis amatorum amator, in pauperum necessatibus curiosus, erga ecclesias valde sollicitus; religiosos phylosophosque viros non solum amabat, verum etiam fortiter honorabat. Qui etsi tot virtutibus clarebat, mulierum tamen illecebris eas fedabat (ed. Chiesa, p. 75). Munich, Bayerische Staatsbibliothek Clm 6388, fol. 47v.

118 Antap. III.52.

${ }^{119}$ Leyser, 'Episcopal office in the Italy of Liudprand of Cremona', p. 797. He certainly shows the impressive extent of Liutprand's Biblical knowledge also apparent from his Homily on Easter (ed. Chiesa, pp. 153-165; trans. Squatriti, pp. 203-218), discussed by Karl Leyser, 'Liudprand of Cremona: Preacher and Homilist', in D. Wood and K. Walsh (eds), The Bible in the Medieval World: Essays in Memory of Beryl Smalley, Studies in Church History, Subsidia 4 (Oxford, 1985), pp. 43-60.

${ }^{120}$ Bouchard, 'The Bosonids', p. 420 nt. 41; Buc, 'Italian Hussies and German Matrons'. 
${ }^{121}$ In the Freising manuscript (Munich, Bayerische Staatsbibliothek Clm 6388, fol. 47v) these two names were carefully added by the corrector in red ink. Hubert's name was not Liutprand's invention as it is recorded in several charters, including two where he petitioned in favour of the church of Reggio-Emilia (Schiaparelli, I diplomi di Ugo e Lotario, docs 63 and 69).

${ }^{122}$ Antap. I 39 and II 36.

${ }^{123}$ Antap. I 42.

${ }^{124}$ Antap. III 16-17 intriguingly stating that God wanted Hugh to become Italian king.

125 Antap. III 18.

${ }^{126}$ Lazzari, 'La rappresentazione del legami di parentela', pp. 135-43 and Gandino, 'Aspirare al regno' which shows that Bertha's world-view encompassed both Constantinople and Baghdad.

${ }^{127}$ Sutherland, Liudprand of Cremona, pp. 4-5.

${ }^{128}$ Antap. V 20.

${ }^{129}$ James Fentress and Chris Wickham, Social Memory (Oxford, 1992), pp. 41-86. 
${ }^{130}$ For the anthropologically-influenced methodology of 'outsiders and insiders' see Peter Burke, The historical anthropology of early modern Italy (Cambridge, 1987), pp. 15-24. Although the genres of that period are certainly different from those of the tenth century the overall point about being 'in' or being 'out' is relevant to other periods.

${ }^{131}$ Jane Stevenson, Women Latin Poets. Language, Gender and Authority from Antiquity to the Enlightenment (Oxford, 2005), p. 100.

${ }^{132}$ Fichtenau, Living in the Tenth Century, p. 174, emphasised the need for the king to 'rule himself' and 'conquer his passions', as documented by the provisions of the Council of Trosly held in 909. Contemporary penitential literature supported this view as is evident from Hamilton, 'Inquiring into adultery and other wicked deeds'.

${ }^{133}$ Denique, defuncto, quem praedixi, Hluthario/Pars quaedam plebis fuerat, quae, retro rebellis/Menteque perversa propriis dominis inimica/Restituit Beringarii regnum ditioni/Quod, patre defuncto, raptum violenter ab illo/Olim per manus regis devenit Hugonis (Gesta Ottonis Imperatoris, lines 481-86, ed. Maria Pasqualina Pillola, p. 36). 'At the death of Lothar, whom I mentioned before, a certain group of the people resisted with perverse hostility their proper lords (i.e. Otto) and restored the kingdom to the authority of Berengar, that kingdom which at the death of his father had once been snatched from him by violence and had come into the hands of King Hugh' (my translation).

${ }^{134}$ Balzaretti, 'Men and sex', pp. 148-50. 